УДК 51(092)

\author{
A. PlichKo
}

\title{
TWO REMARKS ON THE BOOK BY ROMAN DUDA "PEARLS FROM A LOST CITY. THE LVOV SCHOOL OF MATHEMATICS"
}

\begin{abstract}
A. Plichko. Two remarks on the book by Roman Duda "Pearls from a Lost City. The Lvov School of Mathematics", Mat. Stud. 47 (2017), 211-224.

We consider the murder of Lviv professors and students in July 1941, mentioned in the book by Roman Duda "Pearls from a Lost City. The Lvov School of Mathematics".
\end{abstract}

Papers on the history of Lviv mathematics, including the World War II period, meet a non-mathematical event of July 1941 - the murder of professors and students. Its presentation in literature on history of mathematics is far from the scientific rigor and reflects political views, ideological concepts and national emotions of authors. We will illustrate this phenomenon by the well-known book of R. Duda ([1]). It is not an exception among abundant similar (both historical-mathematical and completely non-mathematical) literature, whose authors are often professional scientists. We start by two quotes.

«The circumstances of this atrocity remain unclear to this day, though the collaboration of Ukrainian nationalists does not appear to be beyond all reasonable doubt. According to S. S. Nicieja, the list [of professors to be murdered] was "drawn up by Ukrainian nationalists biding their time at the OUN (Organization of Ukrainian Nationalists) center in Cracow and by former students of Lvov colleges who had escape Lvov before it was taken over by the Red Army. Here the vested interest of the Nazis and of OUN members coincided. The Germans wanted to liquidate the Polish intelligentsia; the Ukrainians sought the dePolonification of Lvov". Reference: [2]. The people who compiled the list remain unknown to this day. Ukrainian collaboration is in any case indicated by the Ukrainians themselves; for example Boris Lewickyj states, "Ukrainians from nationalist circles helped the Germans by drawing up a list of members of the Polish intelligentsia, the de-Polonification of Lvov being their motivation". Reference: [3]; see also [4, p. 12]. The manner, by which the dePolonification was carried out indicates that there were cases in which the adult family members, guests, and attendants found at the flats of arrested professors were also taken away and subsequently murdered» [1, p. 143-145]. The English translation interprets the words of Nicieja non-exactly. In the Polish origin, Nicieja writes that the list was drawn up not by nationalists and students, but by nationalists who were students.

2010 Mathematics Subject Classification:01A72.

Keywords: Lviv Mathematical School; Massacre of Lviv professors.

doi:10.15330/ms.47.2.211-224

(C) A. Plichko, 2017 
«... as early as July 1941, when the Germans, aided by Ukrainians, murdered more than three thousand Poles and Jews (Reference: [5, p. 243]), including over $200 \mathrm{UJK}^{1}$ students. Footnote: Hundreds of UJK students were arrested on July 11, 1941. They were first taken to the Ukrainian military police ${ }^{2}$ station on Łoziński Street and then transferred to the Gestapo prison (on Pełczyńska Street). Many did not return, and according to Polish Underground sources over two hundred of them were shot» [1, p. 140]. The English translation contains no reference here. The reference in Polish origin: [6].

1. Professors. The eventuality of Ukrainian participation in the murder of professors is considered in [7]. We briefly present the main theses of this paper that relate to compiling of the list.

During the war the Nazis have arrested and murdered many people. Identification and finding of some persons was not simple at all. For example, many Ukrainian nationalists were in the underground and permanently changed addresses and names. However, it is not easy to find publications on drawing up the lists of nationalists to arrest. Instead, a large number of publications is devoted to driving up of the list of Lviv professors. The professors were public persons. It was very easy to identify them and to find their homes. So, here immediately the questions are raised: Why the compilation of professors list is so essential? Why the list was compiled for the Germans by persons of another ethnicity, who were also non-German citizens?

Further, the terms "drawing up" or "compiling" describe no physical process. In particular, they do not indicate on which sources and criteria the list was compiled. However, the simple remembering of "students" immediately makes clear that the list should not be compiled. It already existed. The Polish high schools were publishing annual handbooks (see e.g. [8] or [9]). The books contained addresses, phone numbers and other information about academic teachers. Students regularly purchased these books. Therefore, one cannot speak about the compiling, but only about a selection from the handbooks; and the key problem here is a principle of selection ${ }^{3}$. Duda presents the "de-Polonification" principle.

In our opinion, this principle is false. We will argue by the contradiction. If the purpose of compilers was the de-Polonification, it is likely they would have selected those who realized the Polonification: academic administrators who oppressed the Ukrainians, lawyers, historians; that is leaders, executors and ideologues of the Polish chauvinistic policy. Instead, the list contained almost exclusively physicians, technicians and mathematicians. The majority of the executed did not engage actively into politics. Their political preferences were various. After September 1939 most of them went on to collaborate with the Soviets, which, at least partly, carried out the "de-Polonification" of Lviv, taking away many Poles to Siberia and Kazakhstan. The list contained Germans (F. Groër, nextly released) and Ukrainians (A. Sołowij, shot after all). The names of several arrested professors: F. Groër, R. Longchamps de Berier, A. Sołowij, K. Vetulani, K. Weigel do not look like Polish. Some professors, included into the list were elderly, others had passed away ([12, p. 40]).

The absurdity of selection is obvious, but it follows from the assumption on conscientious preparation of the list by Ukrainians with the de-Polonification purpose. The logic suggests that the assumption itself is absurd. It is more natural to think as follows. Before the GermanSoviet war the Cracow Gestapo received an order to compile a list of Lviv professors to

1. The Jan Kazimierz University.

2. A wrong translation of the Polish word "milicja".

3. The idea that the list can be compiled with help of the high school handbooks, is known; see e.g. [10], [11]. 
be murdered ${ }^{4}$. The order was secret, because the murder was a criminal offense and at that time the bilateral pact on nonaggression with Soviet Union operated. The Gestapo had found persons who compiled the list. These persons could be former Ukrainian, or Polish, or German (volksdeutsche) [10] students who moved from Lviv to Cracow, or perhaps some academic teachers [14, p. 17]. Of course, the Nazis did not let out the state secret. They said something like follows. The German government wants to collaborate with Lviv professors personally. Compile for us a list with addresses ${ }^{5}$. We do not know what the Nazis demanded exactly. However, the persons, who picked out, picked out valuable for Reich (in their opinion) professionals; see $[13$, cover $]$ or $[17]^{6}$. That is why, the physicians were selected from the university academic teachers. For the same reason, two scientists from the Academy of Veterinary Sciences got into the list. The long time ago observed fact that the list contained no declared Jews is also consistent with our hypothesis. The persons, who picked out, knew: the Nazis do not collaborate with Jews. Among the listed there were no professors who had fled to Lviv in 1939 from the western part of Poland. Because their names were absent in the pre-war Lviv high school handbooks.

The end of first quote is difficult to understand and is not identical in the Polish and English editions. It can be interpreted so that, with the de-Polonification intention, the Ukrainians asked Germans to murder also the family members, guests, and attendants of professors, and the request was fulfilled. However, the attendants, both of Polish and Ukrainian origin, were allowed to go, without interesting in their ethnicity. A substantiation of this part of the quote is absent, and the statement itself is questionable.

We advance our own hypothesis. Perhaps, the Nazis planned to murder more professors (40, for example). However, it turned out that for the given time (a night), by the available transport, it is impossible to visit all homes. So one decided to reduce the list of professors, while to add the men from their relatives and guests, and to fulfil the plan ${ }^{7}$. During the arrests, the Nazis found in the apartments of professors J. Grek and T. Ostrowski valuable artistic works (a member of the executing unit, Peter Menten, was versed in the artworks $[14$, p. 20]). Therefore, for the purpose of robbery, they decided to shoot also women from these apartments (the Nazis come back for the women later!). Among killed there were some completely accidental persons, for example, an American citizen Kathy Demko. An additional argument gives topography. The most of arrested university professors lived on the Romanowicz Street or nearby. Perhaps, the university list was longer, but those who

4. We use this term "Gestapo" in the traditional non-formal meaning. D. Schenk [13, p. 147], with an unclear reference, states that the immediate order to prepare the list was given by [the doctor of law!] Karl Schöngarth, the chief of Cracow SD and the future chief of "Lemberg" (Einsatzkommando z.b.V. Lemberg) which has murdered the professors. B. Lewickyj used the term "Galizien" instead of "Lemberg".

5. Nothing suspicious. Then the German Commission for Resettlement in Lviv indeed interested in scientists. Even professor Kazimierz Bartel, the former Polish prime minister, was registered for resettlement to the General Government [Generalgouvernement für die besetzten polnischen Gebiete] [15, p. 164]. By some sources (Polish Wikipedia), Stanisław Kulczyński, a former rector of UJK, mowed at this time to the General Government, but the information is questionable. Moreover, in winter of 1939/40 a group of prominent German persons, that included "abwehrprofessor" Theodor Oberländer, has arrived to Lviv, for an acquaintance with the work of resettlement commission [16, p. 9].

6. A well-known Polish mathematician Stanisław Hartman noted "Otherwise the Berlin killers did not use such selection. There was some mystery here" [18]. The idea that the persons which compiled the list did not knew the real purpose of the compiling is not new; see e.g [19].

7. The idea that firstly "Lemberg" had an order to kill the professors, but not they relatives, probably, belongs to Stefan Banach [20]. 
lived far were deleted. Similar happened with the arrested professors of polytechnic. Most of them lived on the Nabielak Street or nearby. And all these homes were located nearby the Soviet police school, where detainees were brought and the Wuleckie Heights (place of execution $)^{8}$.

Duda bases his statement on publications of a (non-ordinary) Communist Stanisław Nicieja and of a Marxist Boris Lewickyj ([22]). These publications are groundless declarations motivated by ideological positions of their authors. Nicieja did not give any substantiation of his statement. We present the corresponding quote of Lewickyj in details. "Some eyewitnesses who were at this time in Lviv, resp. before the outbreak of German-Soviet war in Cracow, are of the opinion that in compiling of the lists of Polish intellectuals, the Ukrainian nationalistic circles, whose purpose was the de-Polonification of Lviv, helped the Nazis. This relation is certainly not far from truth" ([3]). The names of eyewitnesses are not given. It is unclear what Lewickyj wanted to write. The present tense "are of the opinion" indicates that exactly now, in 1960, the year of well-known processes against the above-mentioned (in that time a Bonn minister) T. Oberländer and the Ukrainian battalion "Nachtigall", the eyewitnesses tell him about the list. That is, formerly they kept silence, not trying to inform the professors about the plan of their massacre, and the Soviet government about the German plan of invasion. Because the execution could be done only after the invasion. Moreover, they did not attempt to make testimonies in the processes against "Nachtigall", but went to Lewickyj. Reading literally, the eyewitnesses made they relation (singular!) together.

I am not the first person who notices the obscurity of Lewickyj's statement, because later he wrote: «Ed. Stakhiv in "Contemporary Ukraine" [Сучасна Україна] dated by February 21 of this year is indignant that I gave as a probable thesis that some Ukrainian elements could help the Nazis in preparation of the lists» (italic belongs to Lewickyj, [23]). So, no eyewitnesses of Lewickyj existed. He simply repeated an old story of Vladimir Belayev, about the "black nationalistic list"; see e.g. [24, p. 84] with a picture of the list ${ }^{9}$. Volodymyr Stakhiv well understood this. Unfortunately, his above-mentioned article «It started with the "black lists"》 is not available for us. The above explanation of Lewickyj is almost non-cited. Instead, the assertion about eyewitnesses is cited often ${ }^{10}$ with emphases like "in any case", "after all", "even"... This propaganda trick is well known. Readers receive an impression that the author has many heavy and well-known arguments to support his thesis, which in any case recognize even the opponents.

However, Lewickyj was an opponent not of Polish Communists but of Ukrainian Nationalists. He was a "defector" (previously Lewickyj had been Nationalist). So, in contrary, an assertion of such a person, who may actually get his information from the East (see below) and which was expressed in a polemic article of Polish journal, should be treated with a special caution.

Lewickyj returned to the black list several times. In particular (we do not know when; he passed away in 1984), Lewickyj «informed the [Polish] prosecutor that a known to him

8. A well-known thesis about preparation of the list by means of a telephone book (see e.g. [21, p. 64], [14, p. 18]) is unlikely. Its exclusive use would give the considerably greater dispersion of professions and addresses of arrested professors. However, it is not excluded that the telephone book was used for establishing of addresses of academic teachers whose data were absent or incomplete in the high school annual handbooks. 9. M. Rudnickii is only a formal coauthor of [24]. V. Belayev, a well-known Soviet writer and collaborator of NKVD, "a very dark person" [темнейший человек] [25], is the author of many popular theses about crimes of Ukrainian nationalists, in particular about they active participation in the murder of Lviv professors. 10. The first such quote [26, p. 76] was appeared almost simultaneously with the article of Lewickyj itself. 
Ukrainian student (sic!) named Moroz, who was working as a translator for needs of a special unit, showed him a day or two before the shooting of Lviv professors a list of people telling "the last time has knocked to these Polish cheats [oszust]"»[27, with the reference: Akta prokuratora $\mathrm{w}$ sprawie zabójstwa prof. polskich wyższych uczelni... (The files of prosecutor concerned the murder of prof. of Polish high schools... ), t. XXII, k. 3246-3247]. Probably, Lewickyj wrote about Yaroslav Moroz, who was not a student at that time and who arrived to Lviv not with "Lemberg" but with the Otto Rasch Einsatzgruppen [28, p. 91]. Ukrainian militia-men, who walked around Lviv with the lists of professors, are not rare in publications. Ukrainian translators are not rare as well. However, a Ukrainian translator-student who walked with a (confidential!) list of professors, there exists in the Eysakowski's interpretation of Lewickyj's information only. Besides, we do not know when and how Lewickyj reached Lviv in July of 1941. Moreover, in [29] he wrote: "Two names ... were given me [podano mi] as quite certain: some [niejaki] Moroz, a former adjutant of colonel Bisanz ..." (italic is mine $)^{11}$. Hence, Lewickyj was not acquainted with Moroz and could not talk with him.

Lewickyj did not inform about an origin of his information. Alfred Bisanz was arrested by Soviets in 1945. In 1949 he gave testimony [30] and mentioned Ya. Moroz, but not as his adjutant. He mentioned Moroz as a University fellow of Roman Shukhevych (who finished his study in 1934). By the Polish Wikipedia, during the World War II A. Bisanz was not the colonel, moreover, he did not serve in army at all. Perhaps, a distorted version of Bisanz' testimony got Lewickyj. He could not or/and did not wish to present an origin of his information. We does not know nothing about the context of this information of Lewickyj.

Anyway, in this, rather made up, conversation Moroz did not use the word "professors" and the term "cheats" did not fit them. Moreover, Lewickyj did not attempt to warn professors about the danger. The most interesting here are relations of Lewickyj with the Polish prosecutors. What we know is that in 1955 he was arrested by the Americans. They suspected that he collaborated with the Soviet intelligence. Allegedly, Lewickyj had a list of Ukrainian immigrants with an information about their contacts with Western intelligence agencies [31]. Of course, the suspicion that Lewickyj compiled this list himself, is uncertain.

Therefore, the statement of Duda about professors is a "way to nowhere" (droga donikąd, see [48]) because it is based on the statements of Nicieja and Lewickyj only, which in turn are based on nothing. It does not matter which, and how many, persons formulate a theorem if they do not give the proof.

Which real relations concerning the list there exist? The only report on a list of professors, compiled by Ukrainian students, is contained in memoirs of Countess Karolina Lanckorońska about a conversation, during her arrest in 1942, with obersturmführer Walter Kutschmann, a former member of "Lemberg". In fact, Kutschmann himself started the conversation about the murder of Lviv professors. "... That night Hans Krüger ordered me to convey the second group of professors according to the list, as well as several others Lviv persons ${ }^{12}$. I reported that nobody was found at the homes, so these persons live.

- Where did you have [skąd mieliście] the lists of doomed from? - I asked.

11. The direct job of Jerzy Giedroyc, the editor of "Kultura", was to ask Lewickyj, how did he get the information. We do not know anything about this question.

12. Indeed, at this very time in the Soviet police school there were also other arrested peoples, probably Jews [21], [7]. 
- Of course [naturalnie], from the useless (hergelaufen) Ukrainian students" ([32] $\left.]^{13}\right)$.

In the retelling of Lanckorońska, Kutschmann's avowal is looked questionable and illogical. On the one hand, he presented himself as almost an "anti-Nazi", who did not carry out the order of arrest (and later of the shooting!), for which he himself may be shot [13, p. 330]. On the other hand, he almost affirmed his participation in the preparing of professors murder. Moreover, Kutschmann used the term "of course" which may indicate that the obtaining of execution lists from Ukrainian students was for him a regular job. A more natural answer to the question of Lanckoronska would be - I do not know. At the same time Kutschmann was preparing a denunciation on untersturmführer H. Krüger, who before informed Lanckorońska about his murder of professors, giving away a state secret. According to Lanckorońska, Kutschmann himself gave away a secret of preparing the murder. Note that Nazi leaderships explained the Lviv executions as a spontaneous revenge for the murder of German captives and repressions of the NKVD. The Nazi informed that Polish intellectuals and Jews helped the NKVD and that this became known after the entering of Germans to Lviv only; see e.g. [13, p. 320] or [15, p. 70]. The personal history of W. Kutschmann, the Gestapo chief in Drohobych ([13, p. 269]), does not allow to trust him completely. Simon Wiesenthal claims that exactly Kutschmann commanded by a military unit which shot professors [13, p. 185]. Wiesenthal presented no origin of his claim. He could have the following reason: Kutschmann informed Lanckorońska that "in Berlin it came to a light, that he refused to shoot the Lviv professors" ([35, p. 1]). Because Kutschmann could not refuse to fulfill the order, he shot professors.

As for Lanckorońska herself, the anti-Ukrainian character of her memories [33] leads also to the doubt in thoroughness of retelling her talk with Kutschmann. Her question is strange. The natural questions would be: Why did you kill the professors? Why did you kill exactly these professors? Lanckorońska was teaching at UJK and knew about the handbooks, where she appears as well [8]. Therefore, she knew that compiling of the professors list is any problem. However, Lanckorońska asks "Where did you have the list from"? She knew that the Nazis did not compile the list themselves. She knew the answer. No matter what actually Kutschmann said. Lantcorońska wrote what she considered to be the truth. Hence, she

- either had heard a gossip about the black Ukrainian lists before (during the war in Lviv circulated a large number of, often incredible, gossips; see e.g. [36, p. 185]),

- or had heard/read about the black lists after the war.

In both cases, she inserted the gossip into the conversation with Kutschmann.

It is hard to remember exactly the words, heard five years ago. For example, Cracow or Lviv students could be easily transformed in the mind of Lanckorońska into Ukrainian ones. The word "Ukrainian" itself means both ethnic and geographical origin. Kutschmann could also say "students from Ukraine"14. We often hear and read not what is said or written, but what we want to hear or read. This phenomenon is illustrated in [7] by examples of Z. Albert, W. Bonusiak and D. Schenk, the authors of publications about the murder of

13. This conversation is quoted and put into own words repeatedly; see. e.g. [21, p. 245], [33, p. 184]. A paraphrase of [34] is cited especially often. It says: "That night he ordered me to convey the second group of professors according to a list which we have obtain from the Ukrainians, who studied in Cracow" (after 1939 almost all Cracow high school was closed). Schenk [13, p. 147], with an unclear reference, states that "the information on them [the professors] brought Ukrainian Lviv University students".

14. The idea that the evidence of K. Lanckorońska should be treated with caution, is not new; see e.g. [14, p. 17]. 
Lviv professors.

To establish the ethnic origin of students, the time of compiling is important. If the list was compiled immediately after the German occupation of Cracow, then the version with "students of Lvov colleges who had escape Lvov before it was taken over by the Red Army" is quite possible. However, if the list was compiled later, after the start of works on the Barbarossa plan, that is in the second half of 1940, then it is unnatural to call these persons as "students". In that time in General Government there appeared new migrants from Lviv of the German, Polish and mixed origin. Among them, of course, there were students and high school teachers (e.g. K. Lanckorońska leaved Lviv at May 3, 1940). Quite naturally, the Gestapo talked with migrants, trying to get a useful information about USSR.

Therefore, the words of Kutschmann have various interpretations. The choice of one interpretation from several possible and the rejection of others is characteristic for propaganda publications. This phenomenon is well-known ([14, p. 18]). Probability Theory states that the multiple repetition of such method gives the final result whose probability is close to zero.

Another record (from 1955) about a "Ukrainian list" belongs to Julia Progulska, the wife of a murdered professor ([21, p. 254]). After arrests, the wives started to search for their husbands. According to Progulska, in a department of Gestapo she obtained the answer: "... it was the Ukrainian list, and we have nothing common with this arrest". Progulska did not ask, for some reason, who has something common with the Ukrainian list. She is looking for her husband yet! Other wives were informed in the Gestapo that professors were arrested by a "Feldgestapo" 15 which went to the front, and they know nothing. It is not clear, what exactly the term "Ukrainian list" means. There were other "Ukrainian" lists. On July 3 the German government ordered to arrest Ukrainian politicians ([37, p. 106]). The arrest was connected with the proclamation of Ukrainian Independence Act of June 30 ([37, p. 13]). So, on July 4 (the date of Progulska visit) the Nazis could compile a list of Ukrainians to arrest. Perhaps, a "Gestapo man" replied (in German!): “... we are engaged in the Ukrainian list and have nothing common with this arrest". Perhaps, the Ukrainian list appeared in the Progulska mind later, when the wives of professors "arrived at a conclusion that the Ukrainian nationalists were the inspirers of arrests" [12, p. 40] (italic is mine). Maybe, the conclusion as well as the term "inspirers" appeared in the mind of professors' wives after reading of the Belayev book [24] (see below) which became popular among the relatives of murdered professors [21]. It is hard to remember exactly the words heard 14 years ago, especially when "arrives at a conclusion".

In fact, the Lanckorońska and Progulska recollections do not contradict our hypothesis. Moreover, the words of Kutschmann about "hergelaufen" students support this hypothesis. Unknowingly, the list may be prepared by Ukrainian students as well. We show only to which extend such sort of testimonies are unreliable.

The publications on the black OUN list contain also some "syllogisms". For example:

1. Since the Nationalists have committed many crimes, they have committed also this crime; see e.g. [23]. Another version: Since the Nationalists have collaborated with the German police, they participated in the compilation of the list ([38, p. 119]). These implications work also in the opposite direction. We prove that the story about black OUN list is an invention.

16. Which did not exist and which, probably, was taken from Belayev; see e.g. [24, p. 92]. 
Hence, we may assume that other stories about the OUN are inventions as well. Hence, also, we may assume that the Nationalists have not collaborated with the German police.

2. The next conclusion belongs to Belayev. According to Belayev, he made conclusion about the black OUN list based on an instructions founded in the autumn of 1944 in an American emissary dropped from an airplane over the Lviv region. "When we read this detailed instruction for drawing of black OUN lists, compiled under German dictation, ... items 1 and $2 \ldots$ pointed out definitely who was the first which inspire (see the conclusion of professors' wives before) the Fascists to murder a large group of Lviv scientists" ([24, p. 103]). The sentence is illogical, but its meaning is sufficiently clear. Once the Nationalists planned to compile the black lists of Polish intellectuals, they also compiled the list of Lviv professors to be shot. The instruction itself is published and well-known, although its authors remain unknown. Now the conclusion of Belayev is very popular. Let us analyze it.

- Time. Probably, the instruction was appeared after the list of professors. If, nevertheless, the instruction was appeared before the list then the "students" were not Ukrainians (see before). The instruction recommends to compile the lists after the start of the German-Soviet war. It follows from nowhere that the lists were compiled before the war.

- Transfer to the Gestapo. It follows from nowhere that the members of Bandera part of OUN - authors of the instruction - recommend to transfer the lists to Gestapo, with which they almost did not collaborate (the Bandera OUN collaborated with Abwehr).

- Intention and realization. An intention and a realization are not the same things. For example, the de-Polonification of Lviv, which was planned by OUN, was realized not by OUN at all. The ND (organization of Polish nationalists) planned to clear Poland from the Jews. However, this was realized by others... We know no hard copy of any black OUN list of the Polish intellectuals.

- Interpretation. The considered part of instruction allows various interpretations. If it meant the Polish intellectuals, antagonistic to Ukrainians, then the execution list has contain completely other persons. If it meant all Polish intellectuals, then any list of professors is unnecessary. The lists already there exist: the high school handbooks.

Finally, there is no document or testimony on the compiling of the professors list by OUN members ([14, p. 17]). All numerous publications on the black OUN list are based on nothing. The unique alive candidates to be the real witnesses (and more, to be the participants!) of compiling of the list, whose names were known, are the above-mentioned Krüger and Kutschmann. However, they were not asked about the list (although could be). Moreover, questions about the list were posed no to the former members of "Lemberg", nor to the Cracow Gestapo members, nor to the members of OUN.

2. Students. The first part of second Duda's quote is taken from an encyclopedia article [5, p. 243]. In the interpretation of Duda, the beginning of July ended after July 11. However, from the context of encyclopedia article it follows that this beginning ended before July 4 (more exactly, before the murder of professors). Hence, [5, p. 243] does not concern the murder of students. It concerns the "pogrom" and "prison action".

These events are not objects of our note. We will make only several remarks. At June 30 - July 3 in Lviv simultaneously took place a violence of civilians against Jews (the pogrom) and a shouting of Jews, which carried out the bodies of Soviet victims from the prisons, by German soldiers (the prison action). The encyclopedia article does not contain exact references and its information is inexact. For example, it gives a wrong information that 
Prof. S. Ruziewicz, a well-known Lviv mathematician, was arrested in the night from 3rd to 4th July. The encyclopedia number 3000 and the form "Poles and Jews" (in that order!) evoke a well-known statement of Albert Norden, the first secretary of the Committee for German Unity, at a press conference in 1959 that "Nachtigall" murdered in Lviv 3000 Poles and Jews ([14, p. 153]). Norden, as well as the encyclopedia, does not present any calculation which lead to this number. It is a typical situation. The numbers play in History the same role as in fairy-tales.

There is a great amount of propaganda publications about the pogrom. They give an unlikely large number of victims and transfer the victims of prison action to the victims of pogrom. Here is a typical quote: "During a short time the Ukrainians killed [during the pogrom] a few thousand people. The Germans did not bother them" ([39, p. 128]). We present shortly more realistic accounts.

A mostly plausible number of Jewish victims of the prison action is several hundreds ([40, p. 376-379]). The Soviet accusation at the Nuremberg Trials also valued the number of victims of the prison action at several hundreds not mentioning, for natural reasons, the prisons themselves ([41, p. 93]). According to Yevhen Nakonechnyi, in summer of 1941 the Polish mathematician Marceli Stark estimated the number of Jews, killed during the prison action, on about 300 people ([42]). Probably Stark made no calculations but repeated Jews rumors.

The number of pogrom victims is relatively small ([40, p. 377], [43, p. 102 $\left.{ }^{16}\right)$. Petro Nakonechnyi, the father of Ye. Nakonechnyi, counting the Jewish funeral immediately after the event, estimated the number of killed during the pogrom for about ten people ([42]). "In my life, I saw two Jewish pogroms. That, on July 1 in Lviv and the second, on August 1945 in Cracow. I do not know which was more cruel, but the second one was more terrible" ([18]). In that, more terrible, pogrom one person (Róża Berger) was killed and, it seems, four more (the names are unknown, and it is unknown if they really died) ([44]). Finally, let us compare these events with another Lviv "pogrom" in 1918. Then Poles killed from 50 to 150 Jews and about 270 Ukrainians ([45]). In most cases the executors were soldiers and armed civilians from paramilitary units. So, the killers (mostly, armed soldiers) and the number of victims of the Lviv events of 1918 and 1941 are similar.

We do not know the number of Polish victims during June 30 - July 3 as well as any name of any Polish victim during this period and neither any name of Jews victim of the pogrom.

The continuation of Duda's statement (about the murder of students) is taken from Jan Draus ([6]). Draus himself took this statement from Grzegorz Hryciuk ([36]):

«11 VII 1941 there were arrested hundreds of young people in general and high school students in particular ...so ... of J.K. students... According to estimates of the Polish Underground, in July 1941 in Lviv was shouted about one hundred of Polish "academicians"». Reference: «AGKBZPNP-IPN, sygn. 787, k. 2, List K. Ohly i Furmankiewicza do J. Cyrankiewicza z 23 III 1947 r. (Letter of K. Ohl [?] and Furmankiewicz to J. Cyrankiewicz from 23 III 1947). A slightly different course of events: Z. Albert, Lwowski Wydział Lekarski w czasie okupacji hitlerowskiej 1941-1944 (The Lviv Medical Faculty during the Nazi occupation 1941-1944), Wrocław, 1975, p. 74. See also AAN, sygn. 202/III-198, k. 128; sygn. 203/XV-8, k. 96; Boss., Sygn. 16711/II, J. Rogowski, Lwów, k. 80».

16. Struve concluded this on the basis of Jewish testimonies. Of course, the exactness of testimonies should be a subject of separate studies. 
The next mention of this event by Hryciuk said: «In July 11 of 1941 there were arrested, and very probably executed, more than hundred of "academics" - the Lviv high schools students» [46]. References: «AAN, 203/XV-8, "Groźba eksterminacji. Sytuacja naWołyniu i Ziemi Czerwieńskiej. Przyczyny - skutki - wskazania" ("Threat of extermination. Situation in Volhynia and Cherven Land. Causes - implications - recommendations"), 1943 r., k. 96; AGKBZpNP, 787, List K. Ohly [... ]; Z. Albert, op. cit., p. 74; Kaźń..., p. 35-60».

Let us make some remarks on these statements.

- The first remark concerns the references in almost all historical publications. Hryciuk does not present quotes and even does not retell by his words, what is written in the cited sources. Let us imagine that a mathematician, proving a theorem, refers to a result that keeps in an archive on the other end of the world, and does not write what this result is!

- In fact, the papers [36], [46] contain no reference to an information of the Polish Underground from 1941. Probably, the "List K. Ohly i Furmankiewicza..." (1947) and anonymous "Grózba eksterminacj..." (1943) contain some mentions about information of the Underground, without references. We do not know, wether these documents mention the UJK. In any case, in 1941 the UJK did not exist. It is unclear, whether Hryciuk means the former UJK students or the real students of the Soviet Lviv university. And mostly important, what did the premier Cyrankiewicz answer? Was he not interested in such excellent propaganda material?

- The fragment of Albert's article, relating to the murder of students, contains no references and asserts an impossible event of arrest and shooting by Ukrainian militia (Albert called it police), without a German headship. Militia had no such authority. The source [Kaźń..., p. 35-60] is [21]. It contains no mention about the murder of students.

- The reference to Rogowski is absent in [46]. Note that on July 25, Rogowski saw young (Jewish?) people whom the militia men led to a commissariat on the Kurkowa Street; see [43, p. 113]. Therefore, either Rogowski saw such events several times in various places, or in [36] Hryciuk missed something.

The case of students is different from the professors one, where the events and murdered persons are known in detail. The murder of professors was investigated by several commissions and courts in USSR, Germany and Poland. The quality of investigations is a separate question. However, they existed. There were published quite detailed testimonies of the family members about arrests in almost all professors homes ([21]). Polish testimonies of the shooting also are published. Moreover, there are German testimonies about this event. In the case of students, the situation looks even worse than for the compiling of professors list. There we have at least 3 testimonies (of K. Lanckorońska, J. Progulska and B. Lewickyj) about testimonies of other people, which one can analyze. In the case of students, there are only brief statements of the author which are based on rumors. Probably, the rumors are based on facts that somebody sometime had seen unknown young people conveyed somewhere (see the testimony of Rogowski). During the war there were many similar events; it is too hard to remember the exact dates. The second Hryciuk's "very probably executed" indicates that, in fact, no information about the execution exists. It seems, there exists no information about biding of students in the Pełczyńska prison. In any way, Struve [40] writes nothing about the murder of students, although he cited Hryciuk [36] (and Eliyahu Yones; see below).

A science, based on rumors only, looks exotic. Very probably, the second statement of 
Duda also is a way to nowhere. His statement is based on a book of Draus, which in turn based upon a book of Hruciuk, whose sources are questionable.

There are many publications about the murder of Lviv students. However, they contain no references on documents or testimonies and some authors are unreliable. We present, as examples, two publications.

1. A repeating of Albert's version: "In July 1941 ... there were arrested and killed other distinguished Poles, as well as university students and the graduates of secondary schools [liceum $]^{17}$, who were arrested by the Ukrainian police and after an interrogation at the police office on Łoziński Street in Lviv - they were taken to an unknown for Poles direction and disappeared forever. Among them were e.g. Kazimierz Ostrowski and of the same second name Maciej - the son of a well known Lviv gynecologist or Maria Luks" ([47] $\left.]^{18}\right)$.

2. «At the same time, Fascists of the battalion "Nachtigall" arrested and then murdered about 100 Polish students. In total, during the first days of occupation, Fascists of the "Nachtigall" with the Nazis murdered about 3 thousand persons from Polish intellectuals of Lviv» $\left([49, \text { p. } 37]^{19}\right)$. Let us note, that unlike to the above-cited statement of Norden, here the "Nachtigall" murdered 3 thousand Polish intellectuals alone, without Jews. The terms "at the same time" and "the first days of occupation" do not determine any concrete period. By the way, on July 11 the "Nachtigall" was absent in Lviv.

Hryciuk (as well as Szcześniak and Szota) writes about one hundred of murdered Polish students, and Draus - about over then two hundreds. Perhaps, Duda noticed this and added to Hryciuk's Poles some Jews: "The next Action took place in July 1941. Its purpose was intended to flush out and incarcerate former functionaries in leftist movements, especially young Jews who had belonged to the Communist youth organization, the Komsomol. All the captured suspects were executed in the Lesienice forest near Lvov" ([50, p. 81]). The Polish version ([51, p. 23]) of Yones' book contains this statement with references in Hebrew language: "Testimony JL, p. 23; Friedman's quote in the Diaspora Encyclopedia - Enciklopedija szel Galujot (heb) edited by M. Gelber, v. IV, Jerusalem, Tel Aviv, 1956, p. 608; T. Zaderecki, biMszol Claw haKeres beLwow, Jerusalem, 1982, p. 208". Indeed, Filip Friedman [52] mentioned this event, but without date, the number of victims and references. Probably, other references of Yones are similar. He does not give the exact date of event and does not mention Poles as victims and Ukrainians as executors. There is no doubt, if Yones heard at least one rumor about Ukrainian participation in these arrests, he would have written it.

The mentioned above statement of Yones could be, by Lewickyj words, not far from truth. German documents and Soviet reports indicate that one of the main goals of Nazis was to identify and arrest the Party, Soviet and Komsomol functionaries. Maybe, in July 1941 they realize such action in Lviv against Komsomol functionaries. Maybe, some arrested were shot, others sent to concentration camps, and some others were released. Since the most part of the city population consisted of Poles and Jews, they also consisted most of

17. Then no such school (liceum) existed in USSR.

19. Aleksander Korman is "an author of extremely dubious credibility" [48].

19. The first edition was published in 1973. The book appeared so extravagant (the presented quote illustrates this) that, at the request of the Soviet embassy, the whole edition was removed from sale. 
the arrested. Naturally, the Ukrainian militia could take (as well as could not take) a part in arrests, because it was subordinated to the Germans. In Poland, in such Nazi actions the Polish police could take a part; in Russia - the Russian...

Many members of Ukrainian militia lived after the war and were well-known. For example, Yevhen Vertsiona, the head of Ukrainian militia in Lviv, passed away in 1975. Nobody attempted to make the inquest against them or even posed questions. As in the case of black list, nobody provided a research, limited by multiple propaganda declarations. In our opinion, the research should start with installing of the names and biographies of Lviv Komsomol functionaries of the Polish and Jewish origin. Maybe, some of them indeed were murdered in July 11.

\section{REFERENCES}

1. R. Duda, Pearls from a Lost City. The Lvov School of Mathematics, History of Mathematics, V.40, AMS, Providence, RI, 2014, Translation from Polish.

2. S.S. Nicieja, Martyrologia profesorów lwowskich w lipcu 1941 roku (The martyrdom of Lvov professors in July 1941), in: Leopolis docet, arcade exhibition in Wrocław, in memory of the Lvov Professors murdered in $1941,2001$.

3. B. Lewickyj, Sprawa dr. Oberlaendera (The cause of Dr Oberlaender), Kultura (Paryż), 1/147-2/148 (1960), 171-185.

4. B. Lewycki, Terror and revolution, LTW, Warszawa, 2004 (The first issue in 1965).

5. The PWN Great Encyclopedia, V.16, 2001-2005. (in Polish)

6. J. Draus, Jan Kazimierz University in Lviv. Portrait of a university in the borderlands 1918-1946, Ksiȩgarnia Akademicka, Kraków, 2007.

7. A. Plichko, Toward to problem of participation of Ukrainians in the murder of Lviv professors in summer of 1941 (to 75 anniversary of the event, NTSh Mathematical Commission, aviable at http://www.math.lviv.ua/ntsh/files/ Plichko.pdf.

8. Jan Kazimierz University in Lviv. University staff in the academic year 1938/39, Lwów, 1938.

9. The program of Lviv University of Technology on the academic year 1939/40, Lwów, 1939.

10. G. Hryciuk, Poles - especially dangerous persons, Tygodnik Powszechny, 13.07.2011.

11. Ya. Dovhopolyi, Peter Menten and Lviv execution lists, aviable at http://zaxid.net/,6.12.2012.

12. W. Bonusiak, Who has killed the Lviv professors?, Krajowa Agencja Wydawnicza, Rzeszów, 1989.

13. D. Schenk, A night of killers, Wysoki Zamek, Kraków, 2011, Translation from German.

14. A. Bolyanovskii, The murder of Polish professors in Lviv in July 1941: the facts, myths, investigations, 2011.

15. O. Hnatiuk, Courage and fear, KEW, Wrocław, 2015.

16. V. Belayev, Unmask, Lviv, 1960.

17. M. Przegiętka, Ukrainian (?) list of Polish professors, aviable at http://www.volhyniamassacre. eu/zw2/articles/ 224,Marcin-Przegietka-Ukrainian-List-of-Polish-Professors.html.

18. S. Hartman, Memoirs (Lviv and others), Oficyna "Leopoldinum", Wrocław, 1994.

19. A. Redzik, Department of Law of Lviv University in 1939-1945, Rocznik Lwowski, Instytut Lwowski, Warszawa, 2004. 
20. S. Banach, Polish scientists, murdered by Hitlerians. Antoni Eomnicki - Wtodzimierz Stożek, Czerwony Sztandar, Lwów, 1944, №87.

21. Z. Albert, The murder of Lviv professors. - July 1941, Wydawnictwo Uniwersytetu Wrocławskiego, Wroclaw, 1989.

22. R. Tysa, A brief sketch of Ukrainian Marxism, Historical truth, 01.05.2012.

23. B. Lewickyj, Einsatzgruppen der Sicherheitspolizei, Kultura, 4/150 (1960), 87-90.

24. V. Belayev, M. Rudnickii, Under foreign flags, «Young Guard», Moscow, 1954.

25. Yu. Nagibin, Diary, «Book garden», Moscow, 1996.

26. A. Drożdżyński, J. Zaborowski, Oberländer przez Ostforschung, wywiad i NSDAP do rządu NRF (Oberländer through Ostforschung, secret service and NSDAP to the Government of FRG), Wydawnictwo Zachodnie, Poznań-Warszawa, 1960.

27. P. Łysakowski, Murder of Lviv professors - July 1941, Dzieje Najnowsze, 44 (2012), №3, 71-92.

28. Ye. Stakhiv, Through prisons, underground and borders, «Rada», Kyiv, 1995.

29. B. Lewickyj, Once more about Oberlaender, Kultura, 3/149 (1960), 132-135.

30. M. Berdnik, Shukhevych and Abwehr), First capital. Video channel for real Kharkiv citizens, aviable at http://1stolica.com.ua/?p=91068.

31. B. Berdychowska, Borys Łewycki and "Kultura", Kultura paryska, aviable at http://www. kulturaparyska.com/pl/idee-i-mysli/borys-lewycki-i-kultura.

32. Memories of K. Lanckorońska, Surprise, Orzeł biały, 47(333) (1948).

33. K. Lanckorońska, War memories. 22 X 1939-5 IV 1945, Znak, Kraków, 2002.

34. K. Kulczyńska, The Karla Lanckorońska report, "Odra", 4 (1977).

35. W. Żeleński, Responsibility for the murder of Lviv professors, Wiadomości (Londyn), 17 (1466) (1974).

36. G. Hryciuk, Poles in Lviv 1939-1944. Everyday life, Książka i Wiedza, Warszawa, 2000.

37. W. Kosyk, Ukraine and Germany in the World War II, NTSh, Paris-New York-Lviv, 1993. Translation from French.

38. R. Torzecki, Poles and Ukrainians. The Ukrainian case during the World War II in Second Polish Republic, Wydawnictwo Naukowe PAN, Warszawa, 1993.

39. M. Urbanek, Brilliants. Lviv mathematical school, Iskry, Warszawa, 2014.

40. K. Struve, Deutsche Herrschaft, ukrainischer Nationalismus, antijüdische Gewalt, Walter de Gruyter GmbH, Berlin/Boston, 2015.

41. The Nuremberg Trials, V.5, Legal literature, Moscow, 1991.

42. Ye. Nakonechnyi, Shoah in Lviv, Pyramid, Lviv, 2006.

43. K. Struve, The Einsatzgruppe "Lemberg", Ukrainian militia and "Petlyura Days", on July 25 and 26 , 1941, Issues of the Holocaust history, 6 (2013), 102-124. Translation from German.

44. A. Cichopek, Jewish pogrom in Cracow. August 11, 1945, Żydowski Instytut Historyczny, 2000.

45. Lwów pogrom (1918), English language Wikipedia.

46. G. Hryciuk, German repressions in the Eastern Borderlands of the Second Polish Republic 1941-1944, Pamięć i Sprawiedliwość, 1(12) (2008), 79-112.

47. Dr. A. Korman, Some details of the tragedy in Lviv, Towarzystwo Miłośników Lwowa i Kresów Południowo Wschodnich, Wrocław, 1995.

48. P. Bohdanowicz, The victims of UPA on photos?, Wschodnia gazeta. Kresy, 24.09.2016.

49. A.B. Szcześniak, W.Z. Szota, Way to nowhere, Bellona, Warszawa, 2013.

50. E. Yones, Smoke in the sand. The Jews of Lvov in the war years 1939-1944, Gefen Publishing House, Jerusalem, 2004. 
51. E. Jones, Lviv Jews during the occupation 1939-1945, Oficyna bibliofilów, Lódź, 1999.

52. F. Friedman, The Holocaust of Lviv Jews, Wydawnictwa Centralnej Żydowskiej Komisji Historycznej, Nr 4, Lódź, 1945.

Cracow University of Technology aplichko@pk.edu.pl 